\title{
Effects of breed and slaughter weight on longissimus muscle biochemical traits and sensory quality in pigs
}

\author{
Marjeta Čandek-Potokar ${ }^{\mathrm{a}^{*}}$, Božidar Žlender $^{\mathrm{b}}$, Michel Bonneau $^{\mathrm{c}}$

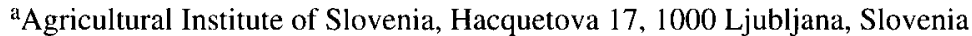 \\ ${ }^{\mathrm{b}}$ Biotechnical Faculty, University of Ljubljana, Jamnikarjeva 101, 1000 Ljubljana, Slovenia \\ 'Station de recherches porcines, Inra, Saint-Gilles, 35590 L'Hermitage, France
}

(Received 17 July 1997; accepted 10 October 1997)

\begin{abstract}
The effects on pig carcass and meat quality of slaughter weight (100 kg vs. $130 \mathrm{~kg}$ ) and breed (Duroc, Landrace and Large White) were investigated. Carcass quality was similar for Duroc and Large White pigs, whereas lower carcass quality was found in Landrace animals. Increased slaughter weight was accompanied by lower carcass quality in the three breeds. Compared to meat from Landrace or Large White animals, meat from Duroc pigs exhibited higher intramuscular fat content, smaller losses at pressing and thawing, redder and more intensive colour, lower resistance to cutting, smaller score for mouth coating and higher scores for fineness (fineness of particles during mastication) and flavour. Increased slaughter weight resulted in higher intramuscular fat content, smaller loss at thawing, redder and more intensive colour (except for Landrace pigs), and reduced scores for tenderness and chewiness. The interactions between breed and slaughter weight for muscle characteristics and pork quality were mostly non-significant. (C) Elsevier / Inra.)
\end{abstract}

pig / breed / weight / pork quality

Résumé - Effets de la race et du poids à l'abattage sur les caractéristiques du muscle long dorsal et la qualité sensorielle de la viande chez le porc. Nous avons étudié les effets du poids à l'abattage (100 kg vs $130 \mathrm{~kg}$ ) et de la race (Duroc, Landrace et Large White) sur la qualité de la carcasse et de la viande chez le porc. La qualité de la carcasse des porcs Landrace est inférieure à celle des porcs Duroc ou Large White. L'augmentation du poids à l'abattage entraîne une réduction de qualité de la carcasse dans les trois races. Comparativement à ce qui est observé chez les animaux de race Large White ou Landrace, le muscle long dorsal des porcs Duroc présente une teneur en lipides intramusculaires plus élevée, une moindre perte d'eau à la pression ou à la décongélation, une couleur plus rouge et plus intense, une moindre résistance au cisaillement, une note plus faible pour le critère de «tapissage de la bouche » (mouth coating) et des notes supérieures pour la finesse (finesse de particules lors de la mastication) et la flaveur de la viande. L'augmentation du poids à l'abattage entraîne un accroissement de la teneur en lipides intra-

* Correspondence and reprints 
musculaires, une réduction des pertes d'eau à la décongélation, une couleur plus rouge et plus intense (à l'exception des porcs Landrace) mais des notes inférieures pour la tendreté et la facilité de mastication. Les interactions entre les effets de la race et du poids à l'abattage sur les caractéristiques du muscle et la qualité des viandes sont pour la plupart non significatives. (৫) Elsevier/Inra.)

porc / race / poids / qualité de viande

\section{INTRODUCTION}

Breed is one of the most important sources of variation in technological and sensory quality of pork $[37,45]$. It has been demonstrated that increased leanness is associated with reduced pork quality (see [46] for review). It is often considered that the eating quality of meat from Duroc pigs is high, due to their high intramuscular fat content. Although the high intramuscular fat content of Duroc pigs is well established, the higher quality of their meat, compared to other modem breeds, is still somewhat controversial $[5,6,11,16$, $31,58]$.

The idea that increasing age at slaughter would improve pork quality is widely accepted among professionals. However, little information is available on whether the variations in age and weight at slaughter, within usual commercial limits, may influence muscle characteristics and sensory quality of pork (e.g. for reviews see $[30,37])$. Increasing age and weight of pigs at slaughter may result in a more intense colour of meat $[9,34,53]$ and higher intramuscular fat (IMF) content [2, $13,27,28,32,38,47]$.

The aim of the present study was to investigate the effect of increasing slaughter weight from 100 to $130 \mathrm{~kg}$ on performance and meat quality of Duroc pigs compared to two other modern breeds exhibiting lower intramuscular fat contents.

\section{MATERIAL AND METHODS}

\subsection{Animals and experimental design}

A total of 116 castrated male pigs of three different breeds (Duroc, Landrace and Large White), raised in a large scale production system ( 85000 pigs per year), were used. The origin of pigs in this herd was the following: Landrace pigs were originally imported from Sweden in the early fifties, Large White pigs from the UK in the early seventies and Duroc pigs from USA in the early eighties, but were thereafter selected according to the Slovene selection programme with occasional introduction of new genes from Denmark and Norway for Landrace.

At weaning, pigs were allotted within litter to two groups which were slaughtered at either 100 (W100) or $130 \mathrm{~kg}$ (W130) live weight. Pigs were housed in groups and fed ad libitum. Six different diets were used successively (table $I$ ). Pigs were transported $20 \mathrm{~km}$ to a commercial abattoir and slaughtered according to routine procedure (electrically stunned $150-200 \mathrm{~V}, 1.3 \mathrm{~A}$; chilled at $4{ }^{\circ} \mathrm{C}$ ). A subsample of 62 carcasses was used for the analysis of meat quality traits.

\subsection{Carcass characteristics}

All measurements and samplings were performed on the left side of the carcass. Carcass measurements were performed on the day of slaughter. Backfat thickness was measured on the split-line at the level of the last rib and at the thinnest point over $\mathrm{m}$. gluteus medius. The cross-sectional area of muscle longissimus dorsi (loin eye area) and the adjacent area of subcutaneous fat (fat area) were measured at the level of the last rib and the ratio of fat to muscle (fat/muscle) was calculated. 
Table I. Energy, protein and lysine content of the diets.

\begin{tabular}{lccc}
\hline Age & Crude protein $(\%)$ & Digestible energy $(\mathrm{MJ} / \mathrm{kg})$ & Lysine $(\%)$ \\
\hline $10-30$ days & 20 & $13.0-13.3$ & 1.2 \\
30-60 days & 19 & 13 & 1.2 \\
60-90 days & 18 & 13 & 1.0 \\
$90-150$ days & 16 & 12.1 & 0.9 \\
$150-210$ days & 14 & 12.1 & 0.8 \\
$>210$ days & 10 & 12.1 & 0.6 \\
\hline
\end{tabular}

\subsection{Muscle sampling and measurements procedure}

The following day the sample for intramuscular fat content and juice loss at pressing was taken and measurement of $\mathrm{pH} 24$ was performed at the level of the last rib. Longissimus thoracis (LT) muscle was then excised between the 8th and 13th vertebrae thoracicae and taken to the laboratory where colour was measured with a Minolta chromameter $200 \mathrm{~b}$ and subjective assessments of colour and marbling were performed. The remaining sample was immediately vacuum-packed and frozen at $-20{ }^{\circ} \mathrm{C}$ for further sensory analysis.

\subsection{Determination of intramuscular fat content}

Samples of meat for the determination of intramuscular fat content were trimmed of all external fat and epimysium. Lipids were extracted according to Folch et al. [19]. Results were expressed as $\mathrm{g} / 100 \mathrm{~g}$ of fresh weight.

\subsection{Muscle quality parameters}

$\mathrm{pH}$ was measured $24 \mathrm{~h}$ post-mortem $(\mathrm{pH} 24)$ at the level of the last rib, using a Testoterm $2300 \mathrm{pH}$ meter with a combined glass electrode. Press loss was measured, using a method modified from Grau and Hamm [21]. Briefly, a $300 \mathrm{mg}$ sample of homogenised muscle was put on filter paper and pressed for $60 \mathrm{~s}$ between two round plates of a hand operated screw press. The amount of expressed fluid absorbed by a filter paper was weighed and expressed as $\mathrm{g}$ per $100 \mathrm{~g}$ fresh tissue. Chromaticity dimensions $\mathrm{L}^{*}, \mathrm{a}^{*}$ and $\mathrm{b}^{*}$ were measured, using $\mathrm{a}$ Minolta chromameter $200 \mathrm{~b}$, and the saturation value $c^{*}$ was computed as $\sqrt{a^{2}+b^{2}}$. Colour and marbling were assessed on fresh meat by five assessors. A 5-point scale was used for colour while visible marbling was rated on a 7 point scale. Higher scores represent stronger intensity of colour or marbling.

\subsection{Sensory quality and texture profile}

Samples for sensory evaluation and measurement of resistance to cutting were thawed overnight at $4{ }^{\circ} \mathrm{C}$ and roasted in an oven at $175^{\circ} \mathrm{C}$ to an internal temperature of $74.9 \pm$ $0.5^{\circ} \mathrm{C}$ (means \pm S.E.M.). Loss of juice at thawing and cooking were calculated as the difference between final and initial sample weights, and expressed as percentage of the initial sample weight.

Five panellists were asked to assess tenderness (at first bites), chewiness (ease of breakdown), fineness of texture (fineness of particles during mastication), mouth coating (abundance of saw-dust like particles coating the mouth), juiciness and flavour on a sevenpoint scale, with intensity increasing from 1 to 7 .

Two slices of roasted LT muscle $(10 \mathrm{~mm}$ thick) were used at room temperature to measure resistance to cutting. An Instron Universal Testing machine, model 1111 , equipped with $10 \mathrm{~mm}$ cutting blade $\left(\Phi=14 \mathrm{~mm}, 60^{\circ}\right.$ angle between sides of the blade) was used (for details, see [59]) and peak cut force (N) measured perpendicular and parallel to axis of muscle fibres. Cross-head speed was $5 \mathrm{~cm} / \mathrm{min}$ and deformation depth was $9.6 \mathrm{~mm}$. Three replicates were made in the core of each slice, giving a total of 6 measurements for each sample. 


\subsection{Statistical analysis}

Data were analysed using a GLM procedure [43]. The model included the effects of weight $(W)$, breed $(B)$, interaction $W \times B$ and litter within breed $L(B)$. Least square means for $\mathrm{W} \times \mathrm{B}$ experimental groups were compared at the $5 \%$ probability level. Overall correlation coefficients (r) between muscle properties were calculated, irrespective of breed or slaughter weight groups, using the CORR procedure [43].

\section{RESULTS}

\subsection{Growth performance and carcass quality (table II)}

Post-weaning growth performance was similar in the three breeds. Age at slaughter and average daily gain from weaning to slaughter were not significantly different between breeds for either of the slaughter weights. For a $30 \mathrm{~kg}$ increase in weight, pigs needed on average 53 more days. Backfat thickness, loin eye area and the adjacent area of subcutaneous fat were all significantly affected by breed and slaughter weight. Large White and Duroc pigs exhibited mostly similar values for carcass traits whereas Landrace pigs had fatter carcasses. The differences between Landrace pigs and the other two breeds for carcass traits were larger at $100 \mathrm{~kg}$ than at $130 \mathrm{~kg}$, the breed $\times$ weight interaction being significant for loin eye area and ratio fat/muscle.

\subsection{Characteristics of muscle longissimus dorsi (table III)}

Intramuscular fat content and marbling score were significantly higher in Duroc than in Large White and Landrace pigs at both slaughter weights. Intramuscular fat content, but not marbling score increased with slaughter weight.

$\mathrm{pH}$ measured $24 \mathrm{~h}$ post-mortem did not differ between breeds or slaughter weights.
Loss at pressing was lower in Duroc than in Large White or Landrace pigs. The lowest loss at thawing was again found in Duroc pigs, the highest in Landrace animals, whereas Large White pigs were intermediate. Loss at cooking was not significantly affected by breed. Slaughter weight had no effect on losses at pressing or at cooking, whereas loss at thawing decreased with weight in all three breeds.

Colour, objective and subjective, was significantly affected by breed and weight. Landrace pigs exhibited lower colour score and higher $\mathrm{L}^{*}$ values than Duroc and Large White animals. Duroc pigs exhibited higher $\mathrm{a}^{*}$ and $\mathrm{c}^{*}$ values than Landrace or Large White animals, the differences being larger at 130 than at $100 \mathrm{~kg}$. The $b^{*}$ value was lower in Large White than in the other two breeds. Colour score increased with weight. The $\mathrm{a}^{*}$ and $\mathrm{c}^{*}$ values also increased with weight in Duroc and Large White pigs, whereas they did not change with weight in Landrace animals, the $\mathrm{W} \times$ $\mathrm{B}$ interaction being significant.

\subsection{Quality of cooked pork (table IV)}

Resistance to cutting was the lowest in Duroc, the highest in Large White, whereas Landrace pigs were intermediate. Tenderness and chewiness tended to decrease from Duroc to Landrace to Large White, however the differences between breeds were not significant $(P=0.08$ for tenderness; $P=0.11$ for chewiness). Meat from Duroc pigs was finer, less mouth coating and exhibited more flavour than that of Landrace or Large White animals. Scores for tenderness and chewiness decreased significantly with slaughter weight in all three breeds.

\subsection{Relationship between intramuscular fat content and cooked pork quality traits}

Intramuscular fat content was significantly related (figure 1) to cutting force 


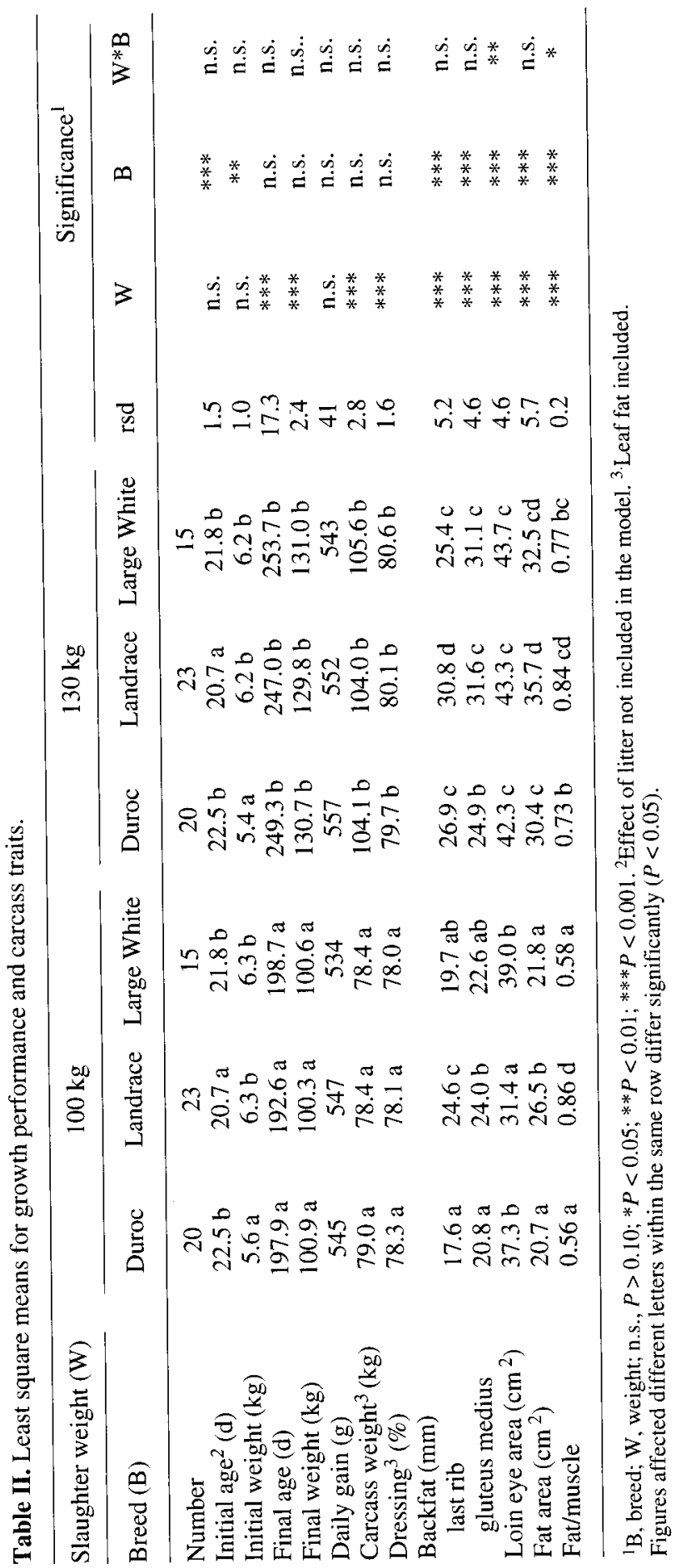




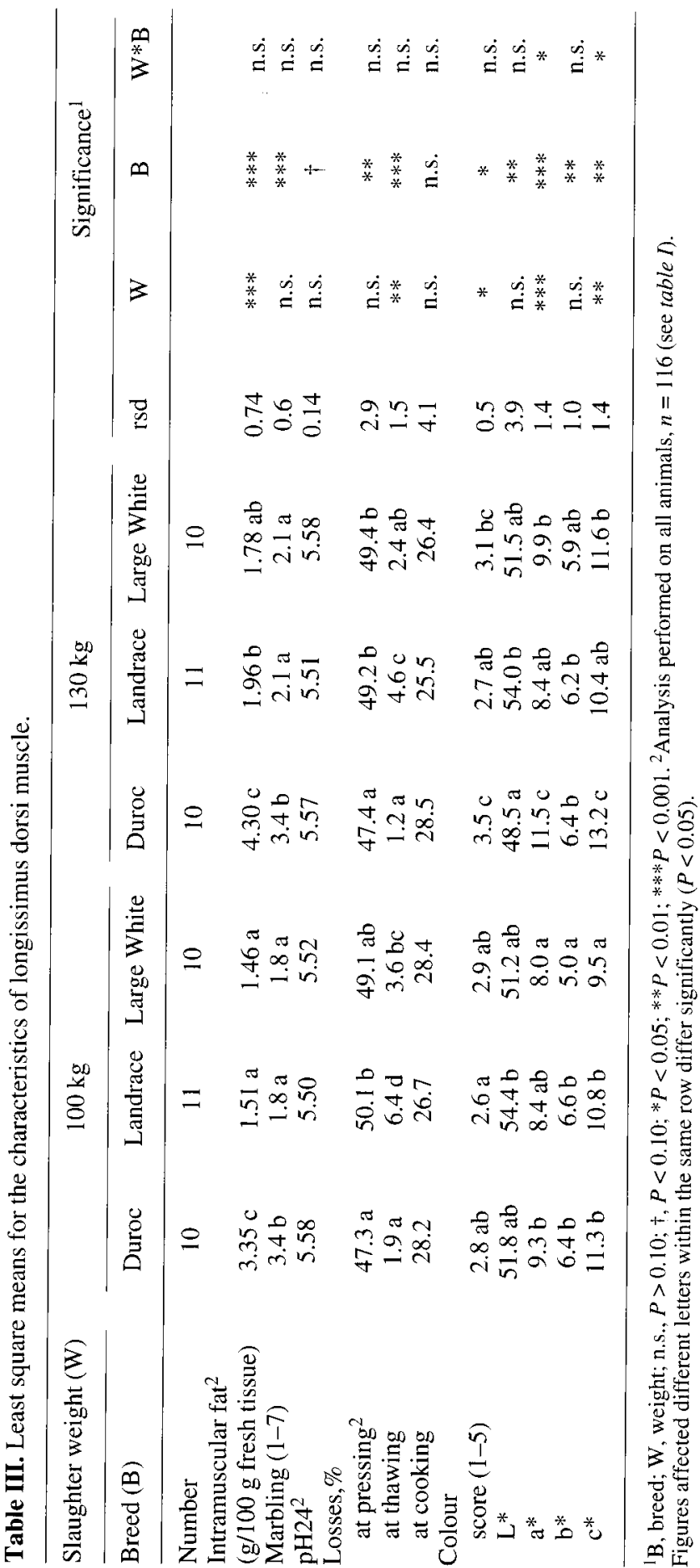




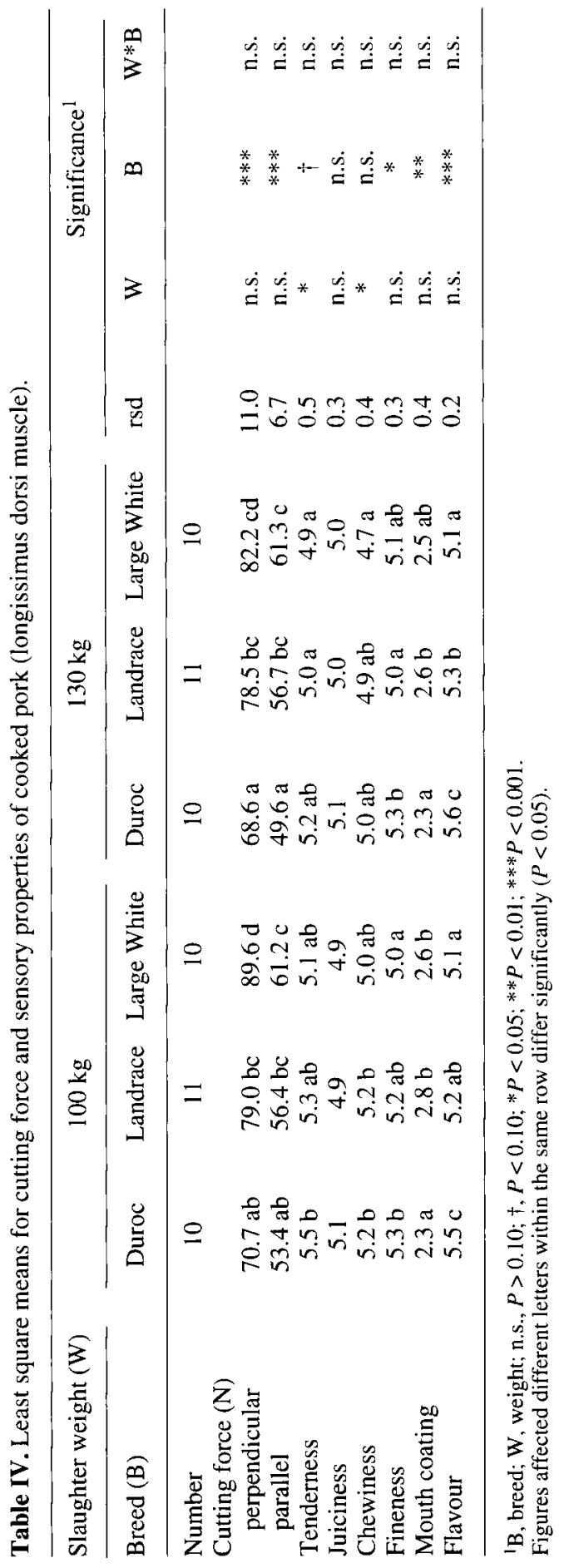



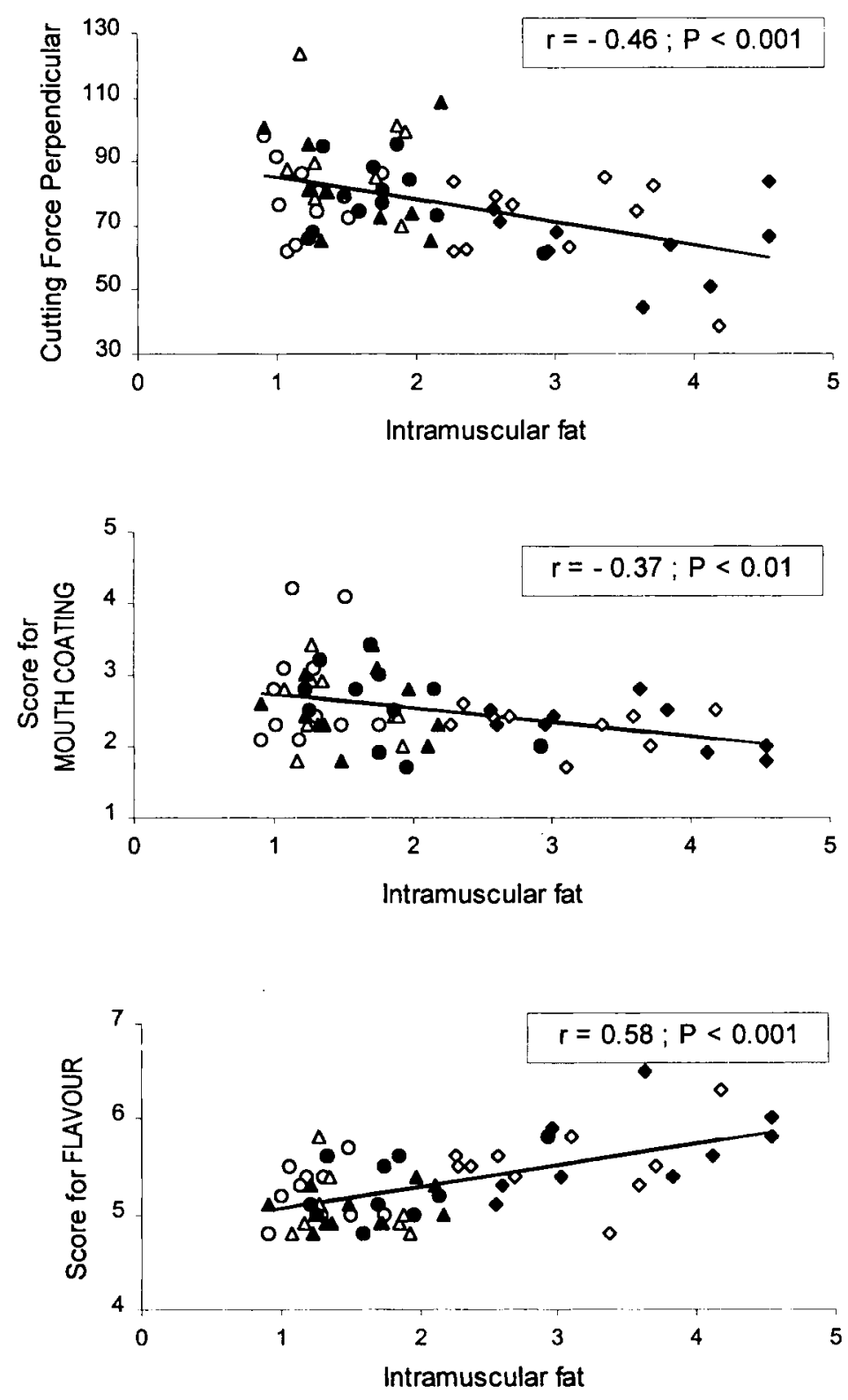
- Duroc 100
- Landrace 100
$\triangle$ Large White 100
- Duroc 130
- Landrace 130
$\triangle$ Large White 130

Figure 1. Relationships $(\mathrm{r})$ between intramuscular fat content $(\mathrm{g} / 100 \mathrm{~g})$ and cutting force $(\mathrm{N})$, mouth coating score (1-7) or flavour score (1-7) in Duroc, Landrace and Large White pigs slaughtered at 100 or $130 \mathrm{~kg}$ live weight. 
(perpendicular $\mathrm{r}=-0.46$; parallel $\mathrm{r}=-0.47 ; P<0.001)$, mouth coating score $(\mathrm{r}=-0.37 ; P<0.01)$ and flavour score $(\mathrm{r}=+0.58 ; P<0.001)$.

\section{DISCUSSION}

\subsection{Growth and carcass quality}

Results from different studies have shown, that Duroc or Duroc-crossed pigs frequently grow faster than pigs of other breeds or strains $[8,35,48,50-52]$. This was not observed in the present experiment where Duroc pigs grew at the same rate as Large White or Landrace animals, in accordance with previous results $[5,17$, 49]. Carcass traits of Duroc pigs in our experiment were similar to those of Large White pigs, whereas both had leaner carcasses than Landrace pigs. A similar hierarchy of the three breeds for carcass characteristics was established by Smith and Pearson [49]. Lo et al. [31] also reported a better carcass quality of pure Duroc as compared to Landrace pigs. In contrast, some European studies do not observe better carcass quality for pure Duroc pigs (see Steane [52] for review). Increase in slaughter weight is accompanied by a lower carcass quality in all breeds, in agreement with the well established effects of slaughter weight on body composition (e.g. [22, $41,57])$.

\subsection{Characteristics of longissimus dorsi muscle}

The higher intramuscular fat content of Duroc pigs, observed for both slaughter weights, is consistent with the previous data obtained in pure or crossbred Duroc pigs $[4-6,17,31,35]$, however, the superiority of Duroc sired pigs for intramuscular fat content has not always been found significant $[33,40]$.
The higher intramuscular fat content observed in $130 \mathrm{~kg}$ than in $100 \mathrm{~kg}$ pigs is consistent with numerous previous findings $[2,13,27,28,32,38,39,47]$, although only slight or no effect of weight, within usually practised slaughter weights, on intramuscular fat content have also been reported $[9,10,15,29,34,44]$.

In agreement with previous observations in pure or Duroc sired pigs $[4,31$, 35], $\mathrm{pH} 24$ did not differ between Duroc and Large White or Landrace pure-bred or crossbred pigs. However, higher $\mathrm{pH} 24$ of Duroc as compared to Landrace or Large White pigs has also been reported [5]. Lower loss at pressing and at thawing in Duroc pigs in the present study, suggest a better water holding capacity, in accordance with Lo et al. [31], who also measured juice loss at pressing, although the difference was not significant in their study. In contrast with the present observation, no difference in drip loss was found between Duroc and Large White or Landrace sired pigs $[35,40]$ or higher drip loss in Duroc than in Large White pigs has been reported [49]. Cooking loss did not differ between Duroc and the other breeds, in accordance with previous observations in Duroc sired pigs compared to Large White or Landrace sired animals [33]. Purchas et al. [40] reported a higher cooking loss in Duroc than in Large White or Landrace sired pigs, however, when corrected for $\mathrm{pH} 24$, this difference was no longer significant.

The effect of slaughter weight on water holding capacity, within usually practised limits, is not conclusive [37]. A beneficial impact of higher slaughter weight and age is reported by Martin et al. [34] and Texier and Daridan [53], whereas other studies found no effect $[29,38,56]$. A study of Cisneros et al. [13] showed a significant increase in drip loss with increase in slaughter weight, but no effect of increased slaughter weight on cooking loss. Our results indicate only a better 
water holding capacity of heavier pigs at thawing, in agreement with the results of Shuler et al. [47]. However, the different methods used for measuring water holding capacity are poorly related to each other $[23,24,55]$.

As for the colour, L* value and colour score show a slightly paler LD muscle of Landrace than Duroc or Large White pigs, in accordance with Barton-Gade [5]. Higher $\mathrm{a}^{*}, \mathrm{c}^{*}$ values suggest a redder, more intensive colour of LD muscle in Duroc pigs. In contrast with our observation, several studies have suggested that pure or crossed Duroc pigs produce paler meat $[4,35,49]$. Moreover, Danish studies reported lower pigment contents in biceps femoris for Duroc and Large White as compared to Landrace pigs [5], or Duroc sired as compared to Large White sired pigs [4]. A study of Martel et al. [33] also indicated a lower pigment content of LD muscle in Duroc sired pigs, however, the difference was not significant. No difference in colour between Duroc and Large White or Landrace pure or sired pigs has been reported [17, 31, 48].

The increase in colour score, $\mathrm{a}^{*}$ and $\mathrm{c}^{*}$ value with weight follows the general idea, that more mature animals produce meat of more intense colour. However, not all studies confirm that trend within usually practised slaughter weights in pigs. Indeed, lower colour score with increasing slaughter weight was reported by Cisneros et al. [13], whereas no weight-related change in colour was observed by Shuler et al. [47], Krieter et al. [27], Leach et al. [29] and Unruh et al. [56]. The latest study indicated, on the basis of $\mathrm{L}^{*} \mathrm{a}^{*} \mathrm{~b}$ measurements, a shift towards darker, less red and intense colour in heavier pigs of very lean genotype, while for the medium lean genotype the values were similar at both weights.

The observed increase in $\mathrm{a}^{*}$ and $\mathrm{c}^{*}$ values in Duroc and Large White pigs, but not in Landrace pigs, can be related to the observation that the rate of myoglobin increase with age in pig muscle varies largely between breeds [3].

\subsection{Quality of cooked pork}

Resistance to cutting was the lowest in Duroc, the highest in Large White and intermediate in Landrace pigs, in agreement with the result of Barton-Gade [5] in Danish pure-bred pigs. Breed tended to affect tenderness and chewiness, again the highest scores were given to Duroc, lowest to Large White and intermediate to Landrace pigs. A better texture of Duroc pigs as compared to Landrace or Large White pigs is in agreement with previous Danish studies in pure-bred $[6,7]$, or crossbred pigs [4]. Tenderness has also been reported to be similar for Duroc or Duroc crossbreeds $[17,31,33,35,40]$. Purchas et al. [40] showed no effect of sire breed on tenderness, but when results were corrected for $\mathrm{pH} 24$, a higher meat tenderness of Duroc than Large White sired pigs was observed.

Juiciness did not differ between Duroc and the other breeds, in contrast with Danish results for Duroc, Large White and Landrace pigs [6, 7]. However, no differences between Duroc, Large White and Landrace pure or sired pigs on juiciness has been reported $[17,31,33,35,40]$.

Meat of Duroc pigs had better flavour, in agreement with numerous findings for pure or crossbred Duroc pigs $[6,7,33,35$, 40]. However, similar flavour has also been reported for pure or crossbred Duroc pigs [17, 31].

The comparison of meat quality traits between Large White and Landrace pigs of the present study showed no statistically important difference, however, results indicate that Large White pigs might produce meat of poorer texture than Landrace pigs. Comparisons between Large White and 'conventional' Landrace breeds for 
eating quality have shown no difference or only a small advantage in favour of Landrace $[45,46]$.

On the whole, our results are in good agreement with the available literature showing that eating quality of meat from pure Duroc or Duroc sired pigs is higher or at least similar to that of other breeds or strains. The better quality of meat from Duroc pigs can to some extent be related to their higher intramuscular fat content $(f i g$ ure l). Contrary to what has been reported in a review study [45], there is no indication from our results of a threshold level for the effect of intramuscular fat on meat quality.

Increasing weight at slaughter reduced tenderness and chewiness. Lower tenderness score with increasing weight in pigs was also reported by Ramaswami et al. [42] and Cisneros et al. [13]. However, no effect of weight on tenderness score has been reported $[29,34,47]$. In the present experiment, lower tenderness at higher weight was not accompanied by higher resistance to cutting. Similarly, Cisneros et al. [13] reported lower tenderness but not higher Warner-Bratzler shear force, with increasing weight, whereas Leach et al. [29] reported just the opposite. Age and weight had no effect on juiciness and flavour, in agreement with the observations of Fjelkner-Mødig [18]. In the present experiment, tenderness and chewiness were reduced with increasing weight at slaughter, in spite of elevated intramuscular fat content. Actually, the beneficial effect of IMF on pork quality is still controversial [20]. A possible explanation for the reduced meat texture of older and heavier pigs is the size of muscle fibres. Increase in fibre diameter has namely been reported to reduce tenderness in pig [12, 42, 54] and beef [14]. Moreover, increase in fibre size is proportional to increase in age and weight $[1,25,26,36,42]$.

\section{CONCLUSIONS}

Our results show that LD muscle characteristics were different in Duroc as compared to two most frequently used modern pig breeds. Meat of Duroc pigs had better water holding capacity, more intense colour and higher intramuscular fat content. Sensory quality of cooked pork was better in Duroc pigs. The increase in slaughter weight resulted in higher, intramuscular fat content and more intense colour. However, tenderness and chewiness of cooked pork were negatively affected.

\section{ACKNOWLEDGMENTS}

The authors are indebted to the management staff of pig farm Emona, Farma Ihan, Slovenia, particularly to Dr. Lucijan Krivec, Mr. Alojz Candek and Mrs. Marta Zajec. This work has been partly supported by the French Ministry for Foreign Affairs and the Slovene Ministry for Science and Technology.

\section{REFERENCES}

[1] Allen E., Forrest J.C., Chapman A.B., First N., Bray R.W., Briskey E.I., Phenotypic and genetic association between porcine muscle properties, J. Anim. Sci. 25 (1966), 962-966.

[2] Allen E., Bray R.W., Cassens R.G., Changes in fatty acid composition of porcine muscle lipid associated with sex and weight. J. Food. Sci. 32 (1967) 26-29.

[3] Barton-Gade P., Some experience on measuring the meat quality of pig carcasses, Acta Agric. Scand. 21 (suppl.) (1979) 61-70.

[4] Barton-Gade P., Meat and fat quality in boars, castrates and gilts, Livest. Prod. Sci. 16 (1987) 187-196.

[5] Barton-Gade P., The effects of breed on meat quality characteristics in pigs, In: Proc. $34^{\text {th }}$ Int. Cong. Meat Sci. Technol., Brisbane, Australia, 1988, pp. 568-570.

[6] Barton-Gade P., Bejerholm C., Eating quality of pork - what Danes have found, Pig Farming (suppl.) (1985) 56-57.

[7] Bejerholm C., Barton-Gade P., Effect of intramuscular fat level on eating quality of pig 
meat, In: Proc. $32^{\text {nd }}$ Eur. Meeting Meat Res. Workers, Ghent, Belgium, 1986, 389-391.

[8] Bereskin B., Performance of selected and control lines of Duroc and Yorkshire pigs and their reciprocal crossbred progeny, $\mathbf{J}$. Anim. Sci. 57 (1983) 867-878.

[9] Berry B.W., Smith G.C., Hillers J.K., Kroening G.H., Effects of chronological age on live and carcass characteristics of Yorkshire swine, J. Anim. Sci. 31 (1970) 856-860.

[10] Bout J., Girard J.P., Lipides et qualités du tissu musculaire, facteurs de variation, In: Journées Recherche Porcine en France 20, 1988, 271-278.

[11] Cameron N.D., Warris P.D., Porter S.J., Enser M.B., Comparison of Duroc and British Landrace pigs for meat and eating quality, Meat Sci. 27 (1990) 227-247.

[12] Carpenter Y.L., Kauffman R.G., Bray R.W., Briskey E.J., Weckel K.G., Factors influencing quality in pork. A. Histological observations, J. Food Sci. 28 (1963) 467-471

[13] Cisneros F., Ellis M., McKeith F.K., McCaw J., Fernando R.L., Influence of slaughter weight on growth and carcass characteristics, commercial cuttings and curing yields, and meat quality of barrows and gilts from two genotypes, J. Anim. Sci. 74 (1996) 925-933.

[14] Crouse J.D., Koohmaraie M., Seideman D., The relationship of muscle fibre size to tenderness of beef, Meat Sci. 30 (1991) 295-302.

[15] Desmoulin B., Girard J.P., Bonneau M., Frouin A., Aptitudes à l'emploi des viandes porcines suivant le type sexuel, le système d'alimentation et le poids d'abattage, In: Journées Recherche Porcine en France 15, $1983,177-191$.

[16] Edwards S.A., Wood J.D., Moncrieff C.B., Porter S.J., Whitehouse J.M., The effect of breed and diet on pig carcass quality, Anim. Prod. 46 (1988), 503 (abstr.).

[17] Edwards S.A., Wood J.D., Moncrieff C.B., Porter S.J., Comparison of the Duroc and Large white as terminal sire breeds and their effect on pigmeat quality, Anim. Prod. 54 (1992) 289-297.

[18| Fjelkner-Mødig S., Eating quality of hams and cutlets from two different cross-bred pigs slaughtered at normal and heavy slaughter weights, respectively, In: Proc. 27th Eur. Meet. Meat Res. Workers, Wien, 1981 , 534-537.

[19] Folch J., Lee M., Sloane-Stanley G.H., A simple method for the isolation and purification of total lipids from animal tissues, J. Biol. Chem. 226 (1957) 497-509.

[20] Göransson $\AA$., Seth von G., Tornberg E., The influence of intramuscular fat content on the eating quality of pork, In: Proc. 38th Int. Cong. Meat Sci. Technol. 2, 1992, 245-248.

[21] Grau R., Hamm R., Eine einfache Methode zur Bestimmung der Wasserbindung in Fleisch, Fleischwirtschaft 4 (1952) 295-297.

[22] De Greef K.H., Werstegen M.W.A., Kemp B., van der Togt P.L., The effect of body weight and energy intake on the composition of deposited tissue in pig, Anim. Prod. 58 (1994) 263-270.

[23] Goutefongea R., Etude comparative de différentes méthodes d'appréciation de l'intensité du caractère exsudatif de la viande de porc, In: Proc. 15th Eur. Meet Meat Res. Workers, Helsinki, 1969, 356-365.

[24] Honikel K.O., The water binding of meat, Fleischwirtschaft 67 (1987) 1098-1102.

[25] Kiessling K.H., Lundström K., Petersson H., Stålhammar H., Age and feed related changes of fibre composition in pig muscle, Swed. J. Agric. Res. 12 (1982) 69-75.

[26] Klosowska D., Klosowski B., Fiedler I., Wegner J., Changes in fiber type distribution and muscle fibre thickness in porcine $m$ longissimus dorsi during growth and relationships between histological characters and carcass parameters, Arch. Tierz. Berlin 28 (1985) 171-180.

[27] Krieter J., Schwerdtfeger R., Hölscher T., Kalm E., Carcass traits, intramuscular fat and meat quality in pigs during the growing period ( $30 \mathrm{~kg}$ to $120 \mathrm{~kg}$ live weight), In: $40 \mathrm{th}$ Ann Meet EAAP, August, 27-31, 1989, Dublin, Ireland.

[28] Lawrie R.A., Pomeroy R.W., Cuthberson A., Studies of the muscles of meat animals III. Comparative composition of various muscles in pigs of three weight groups, J. Agric. Sci. 60 (1963) 195-209.

[29] Leach L.M., Ellis M., Sutton D.S., McKeith F.K., Wilson E.R., The growth performance, carcass characteristics, and meat quality of halothane carrier and negative pigs, J. Anim. Sci., 74 (1996) 934-943.

[30] Lebret B., Lefaucheur L., Mourot J., Bonneau M., Influence des facteurs d'élevage sur la qualité de la viande de porc, In: Journées Rech. Porcine en France 28, 1996, 137-156.

[31] Lo L.L., McLaren D.G., McKeith F.K., Fernando R.L., Novakofski J., Genetic analysis of growth, real-time ultrasound carcass and pork quality traits in duroc and landrace pigs: I Breed effects, J. Anim. Sci. 70 (1992) 2373-2386.

[32] Malmfors B., Lundström K., Hansson I., Fatty acid composition of porcine back fat and muscle lipids as affected by sex, weight and anatomical location, Swed. J. Agric. Res. 8 (1978) 25-38 
133] Martel J., Minvielle F., Poste L.M., Effects of crossbreeding and sex on carcass composition, cooking properties and sensory characteristics of pork, J. Anim. Sci. 66 (1988) $41-46$.

[34] Martin A.H., Sather A.P., Fredeen H.T., Jolly R.W., Alternative market weights for swine II Carcass composition and meat quality, J. Anim. Sci. 50 (1980) 699-705.

[35] McGloughlin P., Allen P., Tarrant P.V., Joseph R.L., Growth and carcass quality of crossbred pigs sired by duroc, landrace and large white boars, Livest. Prod. Sci. 18 (1988) 275-288

[36] Miller L.R., Garwood V.A., Judge M.D., Factors affecting porcine muscle fiber type, diameter and number, J. Anim. Sci. 41 (1975) 1, 66-77.

[37] Monin G., Influence des conditions de production et d'abattage sur les qualités technologiques et organoleptiques des viandes de porc, In: J. Rech. Porcine en France 15, 1983, $151-176$.

[38] Ognjanović A., Perić V., Josipović S., Carcass composition and some quality characteristics of muscle tissue as affected by the age and the weight of pigs at slaughter. In: 19 th Eur. Meet Meat Res. Workers, Paris, France, 1973, 677-695.

[39] Pribiš V., Sijaćki N., Brundža V., Vujošević S., Baletić R., Radić M., Osobine mišiča i kvalitet mesa svinja rase durok u različitoj starosti, Tehnologija mesa 31 (1990) 46-50.

[40] Purchas R.W., Smith W.C., Pearson G., A comparison of duroc, hampshire, landrace and large white as terminal sire breeds of crossbred pigs slaughtered at $85 \mathrm{~kg}$ liveweight 2. Meat quality, New Zealand J. Agric. Res. 33 (1990) 97-104.

[41] Quiniou N., Noblet J., van Milgen J., Dourmad J.Y., Effect of energy intake on performance, nutrient and tissue gain and protein and energy utilization in growing boars, Anim. Sci. 61 (1995) 133-143.

[42] Ramaswami A.M., Jayaprasad A., Radhakrishnan K.T., Kannan G., Influence of slaughter weight on fibre diameter, sarcomere length, shear force value and tenderness score in large white yorkshire barrows, Indian $\mathbf{J}$. Anim. Res. 26 (2) (1992) 67-74.

[43] SAS (1989) SAS/STAT User's Guide, SAS Inst, Inc, Cary, NC.

[44] Schmitten F., Klingelhöller A., Schepers K.H., Festerling A., Einfluss des Mastendgewichtes auf die Fleischbeschaffenheit beim Schwein, Zuchtungskunde 58 (1986) 282-290.

[45] Sellier P., Aspects génétiques des qualités technologiques et organoleptiques de la viande chez le porc, In: Journées Rech. Porcine en France 20, 1988, 227-242.

[46] Sellier P., Monin G., Genetics of pig meat quality: a review, J. Muscle Foods 5 (1994) 187-219.

[47] Shuler R.O., Pate T.D., Mandigo R.W., Lucas L.E., Influence of confinement, floor structure and slaughter weight on pork carcass characteristics, J. Anim. Sci. 31 (1970) 31.

[48] Simpson S.P., Webb A.J., Dick S., Evaluation of jarge white and duroc boars as terminal sires under two different feeding regime, Anim. Prod. 45 (1987) 111-116.

[49] Smith W.C., Pearson G., Comparative voluntary feed intakes, growth performance, carcass composition and meat quality of large white, landrace and duroc pigs, New Zealand J. Exp. Agric. 14 (1986) 43-50.

150| Smith W.C., Pearson G., Garrick D.J., Evaluation of the Duroc in comparison with the landrace and Large White as a terminal sire of crossbred pigs slaughtered at $85 \mathrm{~kg}$ liveweight, New Zealand J. Agric. Res. 31 (1988) 421-430.

[51] Smith W.C., Pearson G., Purchas R.W., A comparison of the Duroc, Hampshire, Landrace and Large White as terminal sire breeds of crossbred pigs slaughtered at $85 \mathrm{~kg}$ liveweight $\mathrm{l}$. Performance and carcass characteristics, New Zealand J. Agric. Res. 33 (1990) 89-96.

[52] Steane D.E., The potential of the duroc breed of pig, Res. Dev. Agric. 3 (1986) 153-157.

[53] Texier C., Daridan D., Influence du poids d'abattage sur la valeur de la carcasse, la qualité de la viande et l'aptitude au séchage du jambon, In: Journées Rech. Porcine en France 8 (1976) 109-113.

[54] Tornberg E., Von Seth G., Göransson $\AA$., Influence of ageing time, storage temperature and percentage lean on the eating quality of pork and its relationship to instrumental and structural parameters, Sci. Alim. 14 (1994) 373-385.

[55] Trout G.R., Techniques for measuring waterbinding capacity in muscle foods - a review of methodology, Meat Sci. 23 (1988) 235-252.

[56] Unruh J.A., Friesen K.G., Stuewe S.R., Dunn B.L., Nelssen J.L., Goodband R.D., Tokach M.D., The influence of genotype, sex and dietary lysine on pork subprimal cut yields and carcass quality of pigs fed to either 104 or 127 kilograms, J. Anim. Sci. 74 (1996) 1274-1283.

[57] Walstra P., Growth and carcass composition from birth to maturity in relation to feeding level and sex in Dutch landrace pigs, Thesis, 
Agricultural University Wageningen, 1980 , $250 \mathrm{p}$.

[58] Wood J.D., Kempster A.J., David P.J., Bovey M., Observations on carcass and meat quality in Duroc, Landrace and Duroc $x$ Landrace pigs, Anim. Prod. 44 ( 1987) 448 (abstr).
[59] Žlender B., Variability of cutting strength and other properties of hot boned beef muscles after various types of conditioning and freezing, Thesis, University of Ljubljana, Biotechnological Faculty, 1982, 86 p. 